\title{
Nitrous oxide fluxes from tropical peat with different disturbance history and management
}

\author{
J. Jauhiainen ${ }^{1}$, H. Silvennoinen ${ }^{2,3}$, R. Hämäläinen ${ }^{2}$, K. Kusin ${ }^{4}$, S. Limin ${ }^{4}$, R. J. Raison ${ }^{5}$, and H. Vasander ${ }^{1}$ \\ ${ }^{1}$ University of Helsinki, Department of Forest Sciences, P.O. Box 27, 00014 University of Helsinki, Finland \\ ${ }^{2}$ University of Eastern Finland, Department of Environmental Sciences, P.O. Box 1627, Kuopio 70211, Finland \\ ${ }^{3}$ Norwegian University of Life Sciences, Department of Plant and Environmental Sciences, Fougnerbakken 3, \\ 1432 Aas, Norway \\ ${ }^{4}$ University of Palangka Raya, CIMTROP, Palangka Raya 73112, Indonesia \\ ${ }^{5}$ CSIRO, Ecosystem Sciences, P.O. Box 1700, Canberra ACT 2601, Australia
}

Correspondence to: J. Jauhiainen (jyrki.jauhiainen@helsinki.fi)

Received: 16 May 2011 - Published in Biogeosciences Discuss.: 1 June 2011

Revised: 13 February 2012 - Accepted: 13 February 2012 - Published: 12 April 2012

\begin{abstract}
Tropical peatlands are one of the most important terrestrial ecosystems in terms of impact on the atmospheric greenhouse gas composition. Currently, greenhouse gas emissions from tropical peatlands following disturbances due to deforestation, drainage or wildfire are substantial. We quantified in situ nitrous oxide $\left(\mathrm{N}_{2} \mathrm{O}\right)$ fluxes during both dry and wet seasons using a closed chamber method at sites that represented differing land uses and land use change intensities in Central Kalimantan, Indonesia. Cumulative $\mathrm{N}_{2} \mathrm{O}$ fluxes were compared with carbon dioxide $\left(\mathrm{CO}_{2}\right)$ and methane $\left(\mathrm{CH}_{4}\right)$ fluxes.
\end{abstract}

The mean $\mathrm{N}_{2} \mathrm{O}$ flux rates $\left(\mathrm{N}_{2} \mathrm{O}-\mathrm{N} \pm \mathrm{SD}, \mathrm{mg} \mathrm{m}^{-2} \mathrm{~h}^{-1}\right)$ varied as follows: drained forest $(0.112 \pm 0.293)>$ agricultural peat at the Kalampangan site $(0.012 \pm 0.026)>$ drained burned peat $(0.011 \pm 0.018)>$ agricultural peat at the Marang site $(0.0072 \pm 0.028)>$ undrained forest $(0.0025 \pm 0.053)>$ clear-felled, drained, recovering forest $(0.0022 \pm 0.021)$. The widest $\mathrm{N}_{2} \mathrm{O}$ flux range was detected in the drained forest ( $\max .2 .312$ and min. $-0.043 \mathrm{mg} \mathrm{N}_{2} \mathrm{O}$ $\mathrm{N} \mathrm{m}^{-2} \mathrm{~h}^{-1}$ ). At the other flux monitoring sites the flux ranges remained at about one tenth that of the drained forest site. The highest $\mathrm{N}_{2} \mathrm{O}$ emission rates were observed at water tables close to the peat surface where also the flux range was widest. Annual cumulative peat surface $\mathrm{N}_{2} \mathrm{O}$ emissions (expressed in $\mathrm{CO}_{2}$ equivalents as a percentage of the total greenhouse gas $\left(\mathrm{N}_{2} \mathrm{O}, \mathrm{CO}_{2}\right.$ and $\left.\mathrm{CH}_{4}\right)$ emissions) were $9.2 \%$ at highest, but typically $\sim 1 \%$. Average $\mathrm{N}_{2} \mathrm{O}$ fluxes and also the total of monitored GHG emissions were highest in drainageaffected forest which is characterized by continuous labile nitrogen availability from vegetation, and water tables typically below the surface.

\section{Introduction}

Global warming is strongly linked to the atmospheric concentrations of the greenhouse gases (GHGs), especially carbon dioxide $\left(\mathrm{CO}_{2}\right)$, methane $\left(\mathrm{CH}_{4}\right)$, chlorofluorocarbon CFC-12, and nitrous oxide $\left(\mathrm{N}_{2} \mathrm{O}\right)$, which has the highest radiative forcing impacts (Solomon et al., 2007). The atmospheric concentration of $\mathrm{N}_{2} \mathrm{O}$ has already increased by $44 \mathrm{ppb}(17 \%)$ since pre-industrial times. $\mathrm{N}_{2} \mathrm{O}$ is very stable in the atmosphere with a lifetime of $\sim 114$ years and it has about a 300 times higher global warming potential (GWP) than that of $\mathrm{CO}_{2}$ on a 100 -year time horizon. Most of the published data on $\mathrm{N}_{2} \mathrm{O}$ fluxes in organic soils have been reported for boreal peatlands (reviewed by Maljanen et al., 2010), whereas only limited data are available for tropical peatlands (Hadi et al., 2000; Inubushi et al., 2003; Kiese et al., 2003; Furukawa et al., 2005; Takakai et al., 2006; Melling et al., 2007).

Soil is considered to be one of the key sources of $\mathrm{N}_{2} \mathrm{O}$ emitted into the atmosphere as it contributes approximately $60 \%$ of the emissions globally (Ehhalt et al., 2001). Processes involved in the dynamics of $\mathrm{N}_{2} \mathrm{O}, \mathrm{CO}_{2}$ and $\mathrm{CH}_{4}$ exchange between soil and the atmosphere are controlled by several factors, including soil moisture status, temperature and mineral nitrogen concentration (Martikainen et al., 1993; Melling et al., 2007; Maljanen et al., 2010). Although the main GHG gas flux direction from decomposition processes is from the soil to the atmosphere, influxes (gas uptake by the soil) have also been detected for $\mathrm{N}_{2} \mathrm{O}$ (Pihlatie et al., 2005; Takakai et al., 2006; Hyvönen et al., 2009) and $\mathrm{CH}_{4}$ (Mäkiranta et al., 2007; Jauhiainen et al., 2008; Maljanen et 
al., 2010). $\mathrm{CH}_{4}$ emissions are at their highest under strictly anaerobic conditions in soil, whereas $\mathrm{CO}_{2}$ emissions predominate under aerobic conditions (Moore and Knowles, 1989). The $\mathrm{N}_{2} \mathrm{O}$ emissions from soils are produced by the microbial processes of nitrification (conversion of $\mathrm{NH}_{4}^{+}$to $\left.\mathrm{NO}_{3}^{-}\right)$and denitrification $\left(\mathrm{NO}_{3}^{-}\right.$to $\mathrm{N}_{2} \mathrm{O}$ or $\left.\mathrm{N}_{2}\right)$. Maximum emissions of $\mathrm{N}_{2} \mathrm{O}$ are typical when intermediate conditions between aerobic and anaerobic states in soil prevail (Davidson et al., 2000). The source of $\mathrm{N}_{2} \mathrm{O}$ often remains uncertain because denitrification and nitrification processes can occur simultaneously in the same soil aggregate (Davidson et al., 1986).

Since 1990, 5.1 Mha of the total 15.5 Mha of peatland in Peninsular Malaysia, and the islands of Borneo and Sumatra, which represent the main tropical peat deposit areas, have been deforested, drained and burned (Miettinen and Liew, 2010). Most of the remainder of this region's peat swamp forests have been logged intensively. Agriculture necessitates permanent drainage of peatlands as there is a need to secure oxygen availability for the roots of crop species grown on peat soils. Lowering of the water table for agricultural purposes in organic soils usually increases $\mathrm{N}_{2} \mathrm{O}$ emissions in the temperate and boreal zones (Kasimir-Klemedtsson et al., 1997; Maljanen et al., 2010). In the tropics, the water table of undrained peat swamp forest fluctuates throughout the year. The forest floor base level is typically flooded for several months during the wet season, whereas the water table recedes a few decimetres below the peat surface during the dry season (Jauhiainen et al., 2005). An increase in oxygen availability during the dry season may lead to enhanced litter and peat decomposition and thus also nitrogen mineralization. In drainage-affected peat swamp forest, prolonged drained conditions may enhance sub-surface litter (fine root) turnover, potentially resulting in further increases in $\mathrm{N}_{2} \mathrm{O}$ emissions. A change in land use from forest to agriculture has been found to enrich the $\mathrm{N}_{2} \mathrm{O}$-producing microorganisms in tropical peat (Yanai et al., 2007; Hashidoko et al., 2008) and to increase $\mathrm{N}_{2} \mathrm{O}$ production (Takakai et al., 2006; Melling et al., 2007). This may be because land clearance and drainage result in an initial increase in the availability of decomposable organic matter in the form of logging residues. $\mathrm{N}_{2} \mathrm{O}$ emissions may remain high if substantial $\mathrm{N}$-fertilizer applications are made to increase agricultural productivity and for plantation forestry on nutrient deficient peat soils (Germer and Sauerborn, 2008; Murdiyarso et al., 2010). Peatland that has been drained, clear felled, burned and that has a sparse, non-woody vegetation cover can be considered as the most extreme land use type where limited litter deposition has an increasing importance in restricting labile organic nitrogen mineralization.
Tropical ombrotrophic peat swamp forest above ground biomass is typically in the range of 100 to $250 \mathrm{tC} \mathrm{ha}^{-1}$ (Murdiyarso et al., 2010; Page et al., 2011), whereas the combined above- and below-ground biomass of undrained ombrotrophic boreal Sphagnum dominated peatland is about $85 \mathrm{tC} \mathrm{ha}^{-1}$ (Laiho et al., 2003). During land use change, the vegetation biomass and nitrogen emissions may be expected to change more in the tropical forested peatlands in comparison to non-tropical peatlands characterized by Sphagnum and sedge communities. In Southeast Asia, repeated fire events are common on drainage affected, degraded peatland with each fire event causing successive losses of vegetation (Hoscilo et al., 2011) and, as a result of peat combustion, exposing older and more recalcitrant peat (Page et al., 2002). Losses in vegetation cover and exposure of poorer soil lead to a reduction in the store of labile nitrogen compounds in the peat system. In peatlands managed for small-scale agriculture, controlled burning of the peat surface and crop residues, in combination with $\mathrm{N}$-fertilization, aim to lower peat acidity and increase nitrogen availability (Takakai et al., 2006). The potential for continuous high nitrogen mineralization rates are possible in the tropics because high temperatures in peat are quite stable throughout the year (Jauhiainen et al., 2008, 2012).

The objective of this study was to quantify $\mathrm{N}_{2} \mathrm{O}$ exchange dynamics between the peat and the atmosphere and to estimate the importance of this greenhouse gas under typical tropical peat land uses. Research questions were: firstly, does the land use, defined by differences in vegetation cover and peat water table conditions, result in differences in $\mathrm{N}_{2} \mathrm{O}$ flux? Secondly, to what extent does annual $\mathrm{N}_{2} \mathrm{O}$ flux balance compare with the balances of the other two main greenhouse gases in peat (i.e. $\mathrm{CO}_{2}$ and $\mathrm{CH}_{4}$ )? The study was conducted by comparing soil - atmosphere $\mathrm{N}_{2} \mathrm{O}$ flux rates across five different land uses under characteristic field conditions and by comparison of cumulative $\mathrm{N}_{2} \mathrm{O}$ fluxes with the previously published $\mathrm{CO}_{2}$ and $\mathrm{CH}_{4}$ balances for the same study sites. The annual peat water table cycle usually differs according to land use, while differences in vegetation and peat characteristics are properties formed over time. Water table depth was selected as the common gas flux controlling factor monitored in this study. Drainage was expected to increase the $\mathrm{N}_{2} \mathrm{O}$ fluxes in sites characterized by forest. In the drained areas, vegetation type and amount was expected to have greater importance for $\mathrm{N}_{2} \mathrm{O}$ fluxes than differences in water table depth. The presence of vegetation and drained conditions, that provide labile carbon and nitrogen and increased oxygen availability for decomposition processes in peat, were expected to enhance the GWP impact of cumulative $\mathrm{N}_{2} \mathrm{O}$ and $\mathrm{CO}_{2}$ emissions, but to decrease it for $\mathrm{CH}_{4}$. 


\section{Methods}

\subsection{Study sites}

Study sites were located within $\sim 20 \mathrm{~km}$ of Palangka Raya city in Central Kalimantan Province, Indonesia. The climate in the area is characterized by a relatively unvarying temperature, high humidity, and high rainfall intensity. The mean monthly temperature varies between 24 and $27^{\circ} \mathrm{C}$. The mean annual rainfall varies between 1900 and $3000 \mathrm{~mm}$ along the southern coast of Borneo, with an overall mean of around $2700 \mathrm{~mm}$ in the study area. The wettest months are December, January and February, whereas the driest months are August and September. The average evapotranspiration is fairly constant at an annual total of around $1350 \mathrm{~mm}$, and it usually exceeds mean monthly rainfall in the July to September dry period (Hooijer et al., 2008).

The study included five land use types. Three of the land use types had forest cover; these were the undrained forest (UF), drained forest (DF), and drained clear-felled but recovering forest (DRF). Land use types on clear-felled drained open peat areas included drained burned peat (DBP) and land drained for agriculture (AP_Ka and AP_Ma) (Fig. 1). The pristine peat swamp forest conditions in this study, both in terms of vegetation status and hydrological conditions, were represented by the UF site in the Sabangau forest (Fig. 1; Tables 1, 2; Jauhiainen et al., 2005). Trees with $\geq 5 \mathrm{~cm}$ diameter breast height comprised over $99 \%$ of trees in the UF site area, with a total aboveground biomass of about $312 \mathrm{tha}^{-1}$ and a total below-ground root biomass of about $26.5 \mathrm{tha}^{-1}$ (Sulistiyanto, 2004). Three of the drainage-affected sites (DF, DRF, DBP) were inside the Ex-Mega Rice Project (EMRP) area, close to its northwest corner (Fig. 1). The EMRP area is about 1000000 ha, and makes up one of the largest continuous areas of degraded tropical peat in the region. This area was clear-felled and drained for food production purposes in the mid 1990s, but many parts have been abandoned because they were found to be unsuitable for the intended agricultural production. The major difficulties encountered were controlling the peat water table and the demanding physico-chemical properties associated with deep peat. The DF, DRF and DBP sites were influenced by one large drainage canal built for water table management. The canal had been originally constructed to be about $25 \mathrm{~m}$ wide with a maximum depth of $4.5 \mathrm{~m}$. The water table in the canal was not controlled and it increased drainage from the area, especially during the dry season. Severe fires in 1997 (Page et al., 2002) had consumed several decimetres of the surface peat and all trees and bushes at the DBP site. Subsequently, the area was taken over by ferns, such as Stenochlaena palustris, which grew on higher surfaces during the flux monitoring period. Data collection and subsequent analyses at the DRF site became limited by a fire event in 2002, which largely removed the vegetation cover. The two agricultural land use sites (Kalampangan and
Marang) were in unvegetated fallow peat outside the EMRP area (Fig. 1). There had previously been either no or very low $\mathrm{N}$-fertilizer inputs at these sites. Peat thickness ranged from $2 \mathrm{~m}$ to $3 \mathrm{~m}$ for the undrained forest site and the Marang agricultural site to about $4 \mathrm{~m}$ for the other sites.

Monitoring locations were positioned on the base (lowest) soil surfaces at the respective study sites. This surface type provided a sufficiently large flat area for air sampling installations, ensured a relatively equal distance from the water table surface, and it was vegetation free at all of the sites. Previous fires had destroyed the original peat surface and created a secondary hummock and hollow/base surface microtopography at the DBP site. The microtopography of the forest floor at the UF, DF and DRF sites comprised of base (hollow) surfaces that were typically free of vegetation, whereas hummocks, which were largely formed from tree root systems, were covered by tree seedlings. The gas sampling technique used in this study required setting up permanent collar installations partly into the surface peat; the root filled hummocks at the forest sites were considered to be too fragile and heterogenic environments for these installations, thus sampling at these sites was only performed in the hollows (discussed in Sect. 4.5). The soil surfaces at the two agriculture sites were flat. Further information on the site characteristics and the gas flux monitoring location setups at individual sites are summarized in Table 1, while information on peat and water table characteristics are shown in Table 2.

\subsection{Sample collection, analysis and data processing}

\subsubsection{Sample collection}

Air samples were taken at 3 to 9 locations from each site (Table 1). Depending on the site, monitoring locations were either randomly positioned or arranged along a transect. Square, open-top aluminium frames with the dimensions $(\mathrm{W} \times \mathrm{L} \times \mathrm{H}) 60 \times 60 \times 40 \mathrm{~cm}$ were used for collecting the air samples. These frames were equipped with a groove for water sealing on the upper edging. They were permanently installed into the peat to a maximum depth of $15 \mathrm{~cm}$ from the lower frame edging. The area enclosed by the frame was kept free of sprouting vegetation by cutting it away at the soil surface level as soon as it emerged. Prior to each sampling event, the frame groove was filled with water, and a $10 \mathrm{~cm}$ high lid was placed on the groove to form a closed chamber for air sampling. A fan mounted inside the chamber mixed the air. For each gas flux determination, four air samples were drawn into $60 \mathrm{ml}$ syringes from the inlet of the chamber lid at $5 \mathrm{~min}$ intervals over a $20 \mathrm{~min}$ enclosure period. Prior to sampling, $20 \mathrm{ml}$ glass vials were filled with nitrogen $\left(99.5 \% \mathrm{~N}_{2}\right)$ and made airtight by sealing them with rubber septa for sample storage before analysis. During sampling these vials were flushed with $40 \mathrm{ml}$ of the sample air and then over-pressurized with the remaining $20 \mathrm{ml}$. From 2002 onwards, $12 \mathrm{ml}$ evacuated glass vials (Labco Extainer) 
Table 1. Key characteristics of the gas flux monitoring sites, and details of the gas flux sampling regimes used in the study.

\begin{tabular}{|c|c|c|}
\hline $\begin{array}{l}\text { Site/ } \\
\text { Acronym/ } \\
\text { Co-ordinates/ } \\
\text { Reference }\end{array}$ & Site characteristics & Gas flux monitoring arrangements \\
\hline $\begin{array}{l}\text { Undrained forest/ } \\
\text { UF/ } \\
2^{\circ} 19^{\prime} 18.2^{\prime \prime} \mathrm{S} \\
113^{\circ} 54^{\prime} 07.7^{\prime \prime} \mathrm{E} / \\
\text { Jauhiainen et al. (2005) }\end{array}$ & $\begin{array}{l}\text { - forest, selectively logged prior to } 1998 \\
\text { - hummock-hollow microtopography } \\
\text { - not fire affected } \\
\text { - undrained } \\
\text { - humic upmost surface peat and sapric peat at } \\
\text { greater depths }\end{array}$ & $\begin{array}{l}\text { - three sub-sites separated by about } 500-1000 \mathrm{~m} \\
\text { distances } \\
\text { - } 3 \text { monitoring locations randomly within } \\
\sim 100 \mathrm{~m} \text { radius at each sub-site } \\
\text { - air sampling } 4 \text { times a week for } 3-5 \text { weeks dur- } \\
\text { ing dry and wet season in } 2000 \text { and } 2001\end{array}$ \\
\hline $\begin{array}{l}\text { Drained forest/ } \\
\mathrm{DF} / \\
2^{\circ} 20^{\prime} 42.06^{\prime \prime} \mathrm{S} \\
114^{\circ} 2^{\prime} 12.18^{\prime \prime} \mathrm{E} / \\
\text { Jauhiainen et al. (2008) }\end{array}$ & $\begin{array}{l}\text { - forest, selectively logged prior to } 1998 \\
\text { - hummock-hollow microtopography } \\
\text { - not fire affected } \\
\text { - drained (uncontrolled) since mid 1990's } \\
\text { - humic upmost surface peat and sapric peat at } \\
\text { greater depths }\end{array}$ & $\begin{array}{l}\text { - one monitoring transect with } 4-5 \text { gas monitor- } \\
\text { ing locations orientated diagonal to the canal at } \\
\sim 50 \text { m distances between them } \\
\text { - air sampling from } 3 \text { to } 5 \text { times weekly for } 3-5 \\
\text { weeks during dry and wet season in } 2001 \text { and } \\
\text { 2002, and frequent monitoring in } 2004-2007\end{array}$ \\
\hline $\begin{array}{l}\text { Drained recovering forest/ } \\
\text { DRF/ } \\
2^{\circ} 20^{\prime} 26.74^{\prime \prime} \mathrm{S} \\
114^{\circ} 2^{\prime} 16.48^{\prime \prime} \mathrm{E} / \\
\text { Hirano et al. (2009) }\end{array}$ & $\begin{array}{l}\text { - practically clear-felled prior to } 1998 \text { but tree veg- } \\
\text { etation was recovering } \\
\text { - hummock-hollow microtopography } \\
\text { - peat fire affected in } 1997 \\
\text { - drained (uncontrolled) since mid 1990's } \\
\text { - shallow humic surface peat but mostly sapric peat }\end{array}$ & $\begin{array}{l}\text { - one monitoring transect with } 4 \text { gas monitoring } \\
\text { locations lined up diagonally to canal at } \sim 50 \mathrm{~m} \\
\text { distances between them } \\
\text { - air sampling from } 2 \text { to } 3 \text { times weekly for } 3-5 \\
\text { weeks during dry and wet seasons in } 2001 \text { and } \\
2002 \\
\text { - Fire destroyed the site in September } 2002\end{array}$ \\
\hline $\begin{array}{l}\text { Drained burned peat/ } \\
\text { DBP/ } \\
2^{\circ} 20^{\prime} 16.60^{\prime \prime} \mathrm{S} \\
114^{\circ} 8^{\prime} 46.74^{\prime \prime} \mathrm{E} / \\
\text { Jauhiainen et al. (2008) }\end{array}$ & $\begin{array}{l}\text { - practically clear-felled since 1998, grow mostly } \\
\text { ferns } \\
\text { - secondary hummock-hollow microtopography } \\
\text { - reoccurred fire events during 1997/98 and } 2002 \\
\text { - drained (uncontrolled) since mid 1990's } \\
\text { - sapric peat }\end{array}$ & $\begin{array}{l}\text { - one monitoring transect with } 4-5 \text { gas monitor- } \\
\text { ing locations lined up diagonally to canal at } \\
\sim 50 \text { m distances between them } \\
\text { - air sampling from } 2 \text { to } 3 \text { times weekly for } 3-5 \\
\text { weeks during dry and wet season in } 2001 \text { and } \\
\text { 2002, and frequent monitoring in 2004-2007 }\end{array}$ \\
\hline $\begin{array}{l}\text { Agricultural peat in Kalampan- } \\
\text { gan/ } \\
\text { AP_Ka/ } \\
2^{\circ} 17^{\prime} 24.11^{\prime \prime} \mathrm{S} \\
114^{\circ} 1^{\prime} 0.32^{\prime \prime} \mathrm{E} / \\
\text { Hirano et al. (2009) }\end{array}$ & $\begin{array}{l}\text { - clear-felled and drained in } 1980 \text { s, fallow peat, } \\
\text { bare peat } \\
\text { - flat peat surface } \\
\text { - repeatedly burnt surface peat } \\
\text { - drained (shallow) } \\
\text { - sapric peat }\end{array}$ & $\begin{array}{l}\text { - one monitoring sub-site with } 3 \text { gas monitoring } \\
\text { locations randomly within } \sim 100 \text { m radius } \\
\text { - air sampling about } 3 \text { times a week for } 3-5 \\
\text { weeks during dry and wet season in } 2001 \text { and } \\
2002\end{array}$ \\
\hline $\begin{array}{l}\text { Agricultural peat in Marang/ } \\
\text { AP_Ma/ } \\
2^{\circ} 4^{\prime} 27.30^{\prime \prime} \mathrm{S} \text {, } \\
113^{\circ} 46^{\prime} 33.10^{\prime \prime} \mathrm{E} / \\
-\end{array}$ & $\begin{array}{l}\text { - cleared for household farming in late 1990's, fal- } \\
\text { low land taken over by grasses } \\
\text { - flat peat surface } \\
\text { - burnt } \\
\text { - drained (shallow) } \\
\text { - sapric peat }\end{array}$ & $\begin{array}{l}\text { - one monitoring sub-site with } 3 \text { gas monitoring } \\
\text { locations randomly within } \sim 100 \text { m radius } \\
\text { - air sampling from } 2 \text { to } 3 \text { times weekly for } 3-5 \\
\text { weeks during dry and wet season in } 2001 \text { and } \\
2002\end{array}$ \\
\hline
\end{tabular}




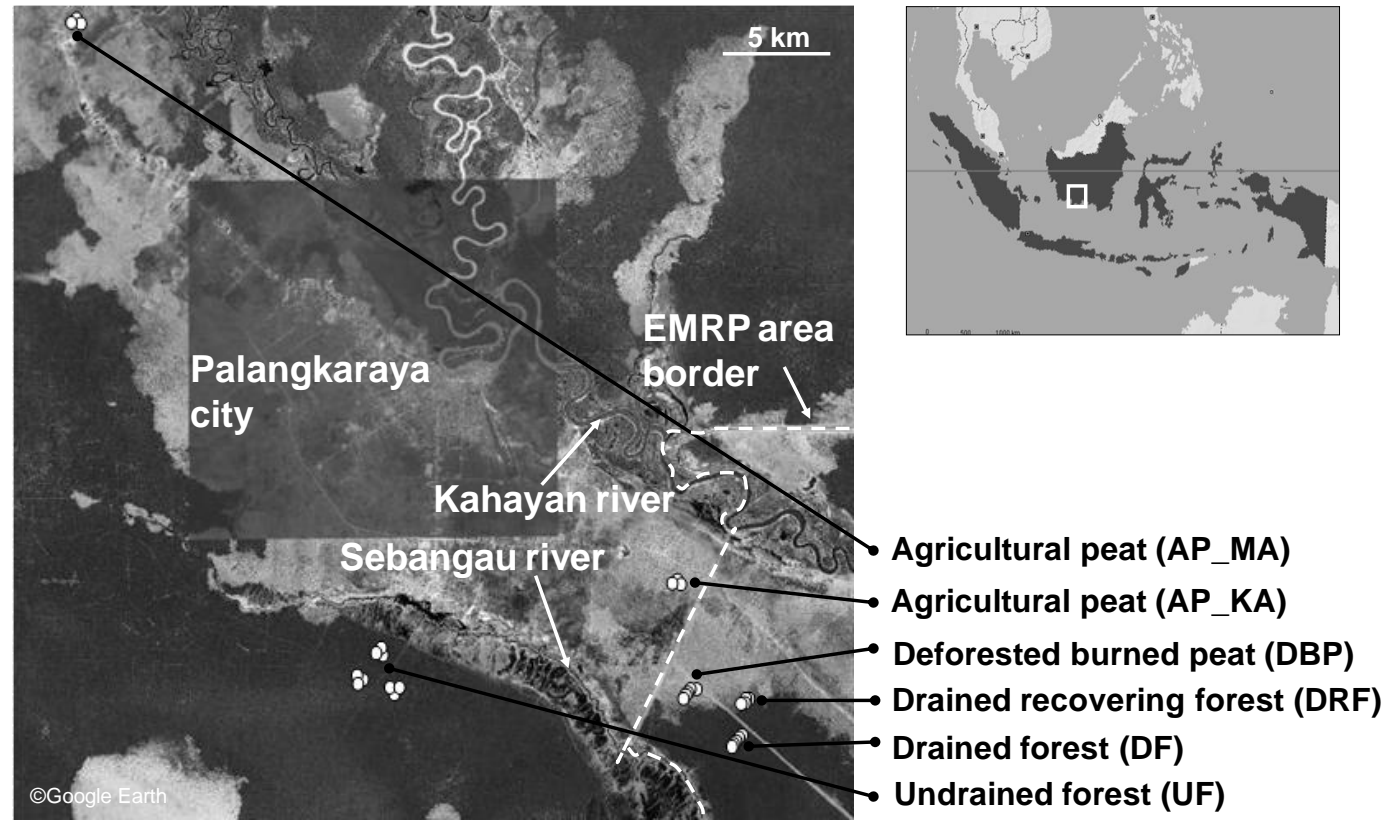

Fig. 1. Greenhouse gas flux monitoring sites in Central Kalimantan, Indonesia. North-East border of Ex-Mega Rice Project area is outlined by the white dotted line.

were used for sample storage by filling each vial with $20 \mathrm{ml}$ of the sample air. Gas impenetrability of the glass vials were ensured during transportation by an additional seal made by hot-melt glue, which was applied to the caps.

\subsubsection{Sample analysis}

Nitrous oxide concentrations from air samples collected during 1999-2002 were analyzed using a gas chromatograph (GC) (Hewlett Packard Series II, Palo Alto, US) equipped with two two-meter long packed columns (Hayesep Q (80/100 mesh), Porapak S (80/100 mesh) and an electron capture detector for $\mathrm{N}_{2} \mathrm{O}$ analysis. After $2002, \mathrm{~N}_{2} \mathrm{O}$ concentrations were analyzed by using a GC (Agilent $6890 \mathrm{~N}$, Agilent Technologies Deutschland GmbH, Waldbronn, Germany) equipped with a peristaltic pump (Minipuls 3, Gilson Inc., Middleton, WI, USA), an autosampler (Gilson autosampler 222XL, Gilson Inc., Middleton, WI, USA) and an electron capture detector for $\mathrm{N}_{2} \mathrm{O}$ analysis. The setup and details of the HP-GC are fully described in Nykänen et al. (1995) and the details of the Agilent-GC in Maljanen et al. (2007). Details of the $\mathrm{CO}_{2}$ and $\mathrm{CH}_{4}$ analyses are provided in the references cited in Fig. 5.

Each $\mathrm{N}_{2} \mathrm{O}$ flux reading was analysed for linearity based on concentrations in consecutive air samples drawn from the closed chamber, and concentration in each sample was also compared with deviation in GC standard gas concentration readings. A determined $\mathrm{N}_{2} \mathrm{O}$ flux readout was rejected when the change in consecutive sample concentrations was less than the deviation in the standard gas samples.

\subsubsection{Water tables at sites}

The peat water table depths of the DF and DBP sites was monitored by installing an automated water table level logger (Keller DCX-22, Winterthur, Switzerland) in one base surface at the most distant gas flux monitoring location, $\sim 300 \mathrm{~m}$, from the canal. Water table data were collected with KADEC-UN and -UP data loggers (Kona System C. Ltd., Sapporo, Japan) at the UF, DRF and AP_Ka sites. The longterm, water table depth data provided by these data loggers were the same as reported in previously published $\mathrm{CO}_{2}$ and $\mathrm{CH}_{4}$ studies (Jauhiainen et al., 2005, 2008; Hirano et al., 2009).

During the air sampling events, water table depths were measured manually by using a dipwell placed next to each gas flux monitoring location. Soil surface level differences between each gas monitoring location (manually recorded water tables) and water table logger location (continuous water table data) in each site were compared and the small water table depth differences were adjusted for in subsequent water table depth calculations. A summary of the water table range during gas flux monitoring is shown in Table 1. The water table depths were expected to differ at those $\mathrm{N}_{2} \mathrm{O}$ monitoring locations that were arranged along a transect diagonal to canal within a $300 \mathrm{~m}$ range of the canal in the drained DF, DRF and DBP sites. However, the differences remained low during air sampling events (Jauhiainen et al., 2008). 
The water table data of the $\mathrm{N}_{2} \mathrm{O}$ flux analysis were divided into classes according to the peat water table depths measured during air sampling. Each of the water table depth classes covered a $10 \mathrm{~cm}$ range and was named according to its mean water table depth class (the water table depth range below the peat surface from $0.05 \mathrm{~m}$ to $0.15 \mathrm{~m}$ was specified as " $0.1 \mathrm{~m}$ class" etc.). Mean daily water table (logger) data, corrected to manually recorded flux monitoring location water tables, were used for cumulative $\mathrm{N}_{2} \mathrm{O}$ flux calculations at the UF, DF, DBP and AP_Ka sites.

\subsubsection{Data analysis}

$\mathrm{N}_{2} \mathrm{O}$ fluxes were calculated from a linear temporal change of gas concentration inside the closed chamber. The mean flux rate for each site (with data from sub-sites pooled together) for each water table depth class (see Sect. 2.2.3) was multiplied by the respective number of days for each water table depth class, and the resultant cumulative fluxes were then summed together to produce cumulative $\mathrm{N}_{2} \mathrm{O}$ fluxes that were integrated over one-year periods. Linear or nonlinear models were not used for the gas flux vs. water table depth calculations because such models would have probably given underestimates of the occasional highly deviating $\mathrm{N}_{2} \mathrm{O}$ flux observations.

Spatial and temporal variations of fluxes were scrutinised in more detail in the data obtained from the DF and DBP sites where the air sampling was carried out at regular intervals (approximately every two weeks) during 2004-2007. For these two datasets, $75 \%$ quartile limits were set as a boundary for separating between those fluxes that differed greatly from the typical flux levels. For statistical comparison of flux means, one-way analysis of variance was applied.

\section{Results}

\section{1 $\quad \mathrm{N}_{2} \mathrm{O}$ flux characteristics}

The majority of the $\mathrm{N}_{2} \mathrm{O}$ flux readings (up to the $75 \%$ quartile limit) were found to be less than $0.02 \mathrm{mg} \mathrm{N}_{2} \mathrm{O}$ $\mathrm{N} \mathrm{m}^{-2} \mathrm{~h}^{-1}$ at most of the sites (Fig. 2; Table 3). However, the exception was the DF site where the limit was $0.08 \mathrm{mg} \mathrm{N}_{2} \mathrm{O}-\mathrm{N} \mathrm{m}^{-2} \mathrm{~h}^{-1}$. As much as $50 \%$ of the readings were $\leq 0.005 \mathrm{mg} \mathrm{N}_{2} \mathrm{O}-\mathrm{N} \mathrm{m}^{-2} \mathrm{~h}^{-1}$ in data obtained from the UF, DRF, DBP, and AP_MA sites. At the AP_KA site, $50 \%$ of the flux readouts were $\leq 0.01$. Negative $\mathrm{N}_{2} \mathrm{O}$ fluxes, i.e. influxes into the soil, occurred at all sites although detected influxes were quantitatively the minor part of the flux data both in terms of the number of flux events and also by flux rate value. The largest number of detected $\mathrm{N}_{2} \mathrm{O}$ influx events, i.e. over $25 \%$ of the data, was found at the undrained UF forest site.

The $\mathrm{N}_{2} \mathrm{O}$ flux monitoring conducted during monitoring periods (2001-2002 and 2004-2007) at the DF and DBP sites showed a marked $(P<0.05, \mathrm{~F}=5.938$, one-way ANOVA $)$

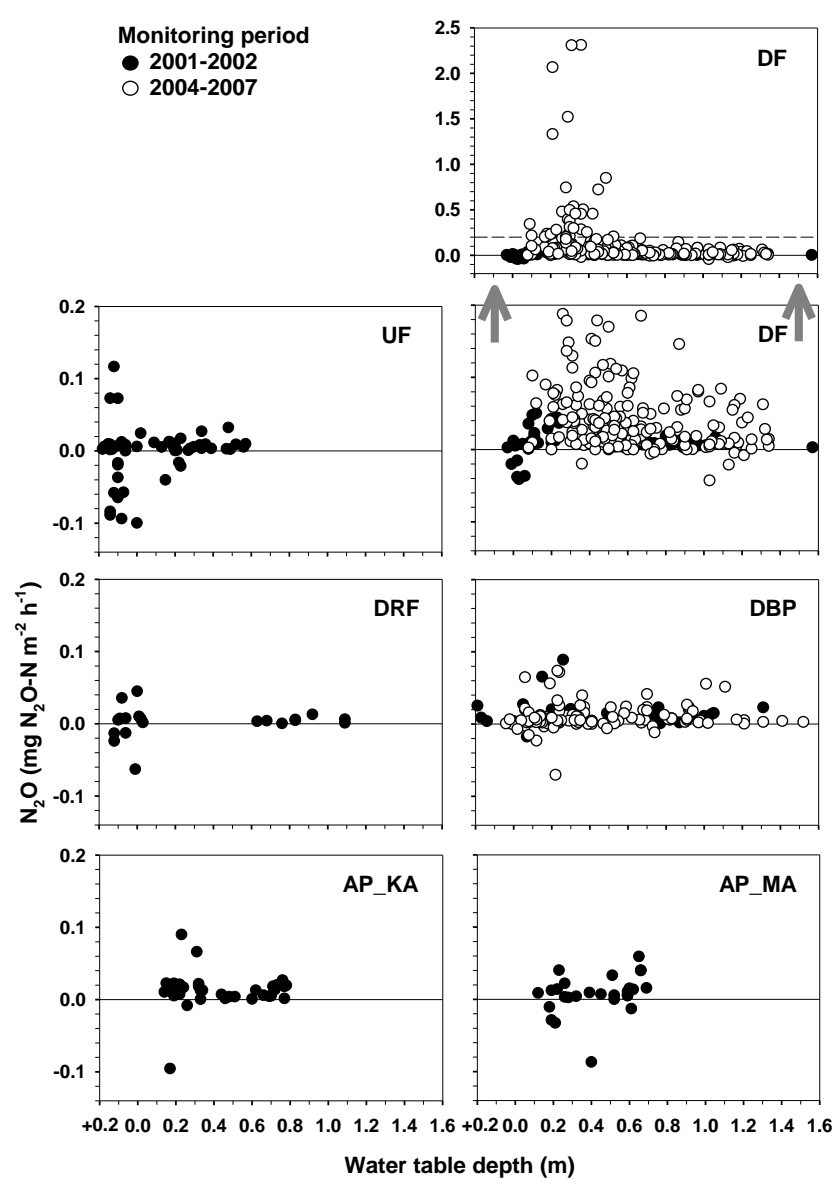

Fig. 2. $\mathrm{N}_{2} \mathrm{O}$ fluxes $\left(\mathrm{mg} \mathrm{N}_{2} \mathrm{O}-\mathrm{N} \mathrm{m}^{-2} \mathrm{~h}^{-1}\right)$ at various water table depths (m). Different forms in circles (if applicable) refer to different gas flux monitoring periods. Two panels are provided for the DF site, one with equal scale to the other sites and one with wider scale (panel which shows all data for the DF site is pointed at by arrows and dotted line in it denotes upper scale limit of the other panels). Site type codes are defined in Fig. 1 and Table 1.

increase in mean flux rates over time at the drainage-affected DF forest and a decreasing trend in mean flux (not statistically significant) rates at the open degraded DBP site (Fig. 2; Table 3).

At most sites, the range of fluxes was wider over a limited water table depth range near the peat surface (Figs. 2, 3). The widest $\mathrm{N}_{2} \mathrm{O}$ flux range (between 2.312 and $-0.043 \mathrm{mg} \mathrm{N}_{2} \mathrm{O}$ $\mathrm{N} \mathrm{m}^{-2} \mathrm{~h}^{-1}$ ) was obtained at the DF site, and these fluxes were scattered over the water table depths between $0.2 \mathrm{~m}$ and $0.4 \mathrm{~m}$ (Figs. 2, 3; Table 3). The next highest range in the $\mathrm{N}_{2} \mathrm{O}$ fluxes was obtained at the UF site, with maximum flux values of about one tenth of those at the DF site. Moreover, the flux range extreme at the DF site was reached when the water tables were at the peat surface. The definitive flux range for the DRF site remains unknown because of a data gap for moderately drained conditions, but the detected flux range was at its widest under flooded conditions. The $\mathrm{N}_{2} \mathrm{O}$ flux 
Table 2. Summary of general peat and water table (WT) depth characteristics at the flux monitoring sites. Means are shown with standard deviations.

\begin{tabular}{|c|c|c|c|c|c|c|c|c|}
\hline & & Sampling depth (m) & UF & DF & $\mathrm{DRF}^{(1)}$ & DBP & AP_KA & AP_MA ${ }^{(1)}$ \\
\hline mean & $m$ & & $0.10 \pm 0.23$ & $0.56 \pm 0.34$ & $0.31 \pm 0.47$ & $0.43 \pm 0.38$ & $0.43 \pm 0.23$ & $0.43 \pm 0.19$ \\
\hline $\max$. & $m$ & & +0.18 & +0.03 & +0.12 & +0.19 & 0.14 & 0.12 \\
\hline \multicolumn{9}{|l|}{ Peat } \\
\hline bulk density & $\mathrm{g} \mathrm{cm}^{-3}$ & $0.1-1.0$ & $0.141 \pm 0.017$ & $0.164 \pm 0.041$ & n.d. & $0.151 \pm 0.036$ & $0.152 \pm 0.022$ & n.d. \\
\hline \multirow[t]{2}{*}{ C-content } & $\%$ & $0.1-0.15$ & $55.3 \pm 0.7$ & $54.3 \pm 2.4$ & $57.9^{(3)}$ & $58.2 \pm 0.26$ & $57.9 \pm 2.50$ & n.d. \\
\hline & $\%$ & $0.1-1.0$ & $58.0 \pm 2.8$ & $58.6 \pm 3.4$ & n.d. & $57.2 \pm 0.80$ & $56.9 \pm 4.64$ & n.d. \\
\hline \multirow[t]{2}{*}{ N-content } & $\%$ & $0.1-0.15$ & $1.6 \pm 0.04$ & $1.7 \pm 0.01$ & $1.7^{(3)}$ & $0.84 \pm 0.08$ & $0.91 \pm 0.06$ & n.d. \\
\hline & $\%$ & $0.1-1.0$ & $1.4 \pm 0.38$ & $1.04 \pm 0.4$ & n.d. & $0.76 \pm 0.08$ & $0.82 \pm 0.07$ & n.d. \\
\hline
\end{tabular}

${ }^{1}$ Some of the data were not determined (n.d.) because the site conditions were changed before soil sampling, i.e. due to fire at the DRF site and due to farming activities at the AP_MA site.

(2) Mean of 3-5 measurements determined from the samples collected from peat profile. Measured from suspension of volumetric mixture of peat and deionised water (1:2) by WinLab Data line $\mathrm{pH}$ meter.

(3) Adopted from Takakai et al. (2006).

Table 3. Summary statistics on $\mathrm{N}_{2} \mathrm{O}$ fluxes $\left(\mathrm{mg} \mathrm{N}_{2} \mathrm{O}-\mathrm{N} \mathrm{m}^{-2} \mathrm{~h}^{-1}\right)$ at monitoring sites.

\begin{tabular}{llllllllll}
\hline Site & Observation period $\left.{ }^{*}\right)$ & $\mathrm{N}$ & Mean & $\mathrm{SD}$ & Min. & Max. & 25\%ile & 50\%ile (Median) & 75\%ile \\
\hline UF & 1 & 54 & 0.0025 & 0.0528 & -0.0998 & 0.1166 & -0.0040 & 0.0054 & 0.0098 \\
DF & 1 & 41 & 0.0106 & 0.0207 & -0.0409 & 0.0504 & 0.0053 & 0.0090 & 0.0185 \\
& 2 & 209 & 0.1313 & 0.3164 & -0.0428 & 2.3120 & 0.0134 & 0.0397 & 0.1016 \\
& 1 and 2 & 250 & 0.1115 & 0.2928 & -0.0428 & 2.3120 & 0.0098 & 0.0315 & 0.0806 \\
DRF & 1 & 20 & 0.0022 & 0.0213 & -0.0629 & 0.0449 & 0.0006 & 0.0050 & 0.0076 \\
DBP & 1 & 31 & 0.0148 & 0.0193 & -0.0174 & 0.0889 & 0.0039 & 0.0113 & 0.0201 \\
& 2 & 109 & 0.0096 & 0.0178 & -0.0705 & 0.0736 & 0.0020 & 0.0052 & 0.0127 \\
& 1 and 2 & 140 & 0.0107 & 0.0182 & -0.0705 & 0.0889 & 0.0024 & 0.0058 & 0.0155 \\
AP_KA & 1 & 35 & 0.0123 & 0.0259 & -0.0955 & 0.0901 & 0.0045 & 0.0127 & 0.0195 \\
AP_MA & 1 & 27 & 0.0072 & 0.0275 & -0.0868 & 0.0593 & 0.0024 & 0.0088 \\
\hline
\end{tabular}

(*) Observation period refers to time of gas flux sampling at DF and DBP sites where pilot study (1) monitoring preceded a longer (2) gas flux monitoring period. See Table 1 for further details. 


\section{Drained forest (DF)}
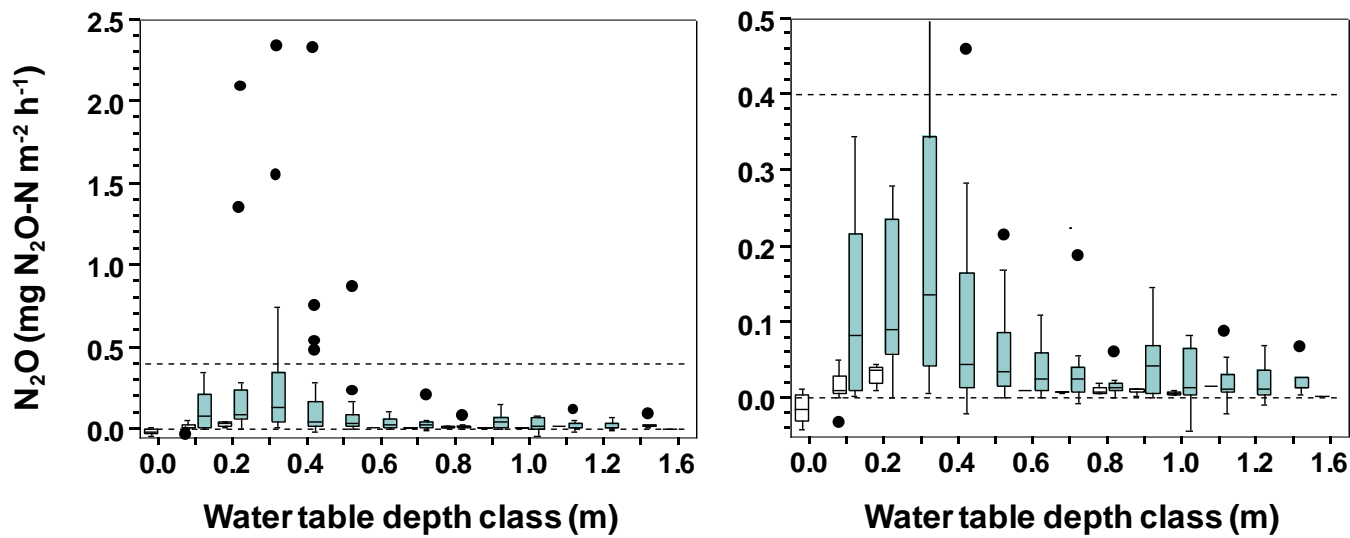

Fig. 3. Boxplot of median, quartiles and extreme $\mathrm{N}_{2} \mathrm{O}$ fluxes $\left(\mathrm{mg} \mathrm{N}_{2} \mathrm{O}-\mathrm{N} \mathrm{m}^{-2} \mathrm{~h}^{-1}\right)$ at various water table depth classes (m) at the DF site. Open boxes denote fluxes for monitoring period 2000-2001 and shadowed boxes for 2004-2007. Panel on left is with scale showing all data and panel on right shows details with smaller scale (dotted lines denote scale limit of the other panel and zero flux).

range at the DBP site data was slightly wider at $0.1-0.3 \mathrm{~m}$ water table depths (Fig. 2; Table 3). At the two permanently drained agricultural sites $\mathrm{N}_{2} \mathrm{O}$ fluxes were scattered seemingly at random over the water table depth range (Fig. 2).

\subsection{Spatial and temporal variation in $\mathrm{N}_{2} \mathrm{O}$ fluxes}

Data collected from five flux monitoring locations in the drained forest (DF) site included 62 flux readings in excess of $0.0806 \mathrm{mg} \mathrm{N}_{2} \mathrm{O}-\mathrm{N} \mathrm{m}^{-2} \mathrm{~h}^{-1}$, which was the determined boundary for the high emission range at the $75 \%$ quartile limit (Fig. 4; Table 3). Contributions from the five flux monitoring locations to the high flux values group were; 10, 31, 23,18 , and $19 \%$, along the transect which lead away from the canal. The mean flux $( \pm \mathrm{SD})$ in this high flux category at the DF site was $0.38 \pm 0.50 \mathrm{mg} \mathrm{N}_{2} \mathrm{O}-\mathrm{N} \mathrm{m}^{-2} \mathrm{~h}^{-1}$ and all individual fluxes in the group were obtained when water tables were relatively close to the peat surface $(0.38 \pm 0.19 \mathrm{~m})$.

The boundary of the high flux rate at the $75 \%$ quartile limit for the deforested burned peat (DBP) site was $0.0155 \mathrm{mg} \mathrm{N}_{2} \mathrm{O}-\mathrm{N} \mathrm{m}^{-2} \mathrm{~h}^{-1}$ (Table 3). The highest $25 \%$ percentile data from the five monitoring locations at the DBP site included 25 flux readings (Fig. 4). Contributions of the individual measurement locations at increasing distance from the canal were; $20,12,8,44$, and $16 \%$. There was no clear association between high flux rates and water table depth (classes) at this site. The mean emission $( \pm \mathrm{SD})$ in the high flux group was $0.033 \pm 0.018 \mathrm{mg} \mathrm{N}_{2} \mathrm{O}-\mathrm{N} \mathrm{m}^{-2} \mathrm{~h}^{-1}$ and the mean water table depth that resulted in this emission was $0.51 \pm 0.33 \mathrm{~m}$.

\subsection{Cumulative $\mathrm{N}_{2} \mathrm{O}$ fluxes}

The drained DF forest site cumulative $( \pm \mathrm{SD}) \mathrm{N}_{2} \mathrm{O}$ emission $\left(1581.3 \pm 41.7 \mathrm{mg} \mathrm{N}_{2} \mathrm{O}-\mathrm{N} \mathrm{m}^{-2} \mathrm{y}^{-1}\right)$ was the highest among the four sites included in this comparison. The UF site annual $\mathrm{N}_{2} \mathrm{O}$ emission was $55.9 \pm 10.3 \mathrm{mg} \mathrm{N}_{2} \mathrm{O}-\mathrm{N} \mathrm{m}^{-2}$, for the deforested DBP site mean annual emission was $76.4 \pm 2.8 \mathrm{mg} \mathrm{N}_{2} \mathrm{O}-\mathrm{N} \mathrm{m}^{-2}$, and for the agricultural AP_Ka peatland site it was $20.6 \pm 7.8 \mathrm{mg} \mathrm{N}_{2} \mathrm{O}-\mathrm{N} \mathrm{m}^{-2}$. The $\mathrm{N}_{2} \mathrm{O}$ flux contribution to the total emission of gases including $\mathrm{CO}_{2}$, and $\mathrm{CH}_{4}$ is shown in Fig. 5 and discussed in Sect. 4.4.

\section{Discussion}

\section{1 $\quad \mathrm{N}_{2} \mathrm{O}$ flux characteristics}

The highest $\mathrm{N}_{2} \mathrm{O}$ flux readings (max. $2.3 \mathrm{mg} \mathrm{N}_{2} \mathrm{O}-\mathrm{N} \mathrm{m}^{-2} \mathrm{~h}^{-1}$ and mean $\left.0.38 \mathrm{mg} \mathrm{N}_{2} \mathrm{O}-\mathrm{N} \mathrm{m}^{-2} \mathrm{~h}^{-1}\right)$ in this study were obtained from the drained forest (DF) site, which were about 10-fold higher than those measured at the other sites. In comparison, the maximum fluxes from other studies were reported to be about one tenth that of the DF site in Padang Alan $\left(\sim 0.200 \mathrm{mg} \mathrm{N}_{2} \mathrm{O}-\mathrm{N} \mathrm{m}^{-2} \mathrm{~h}^{-1}\right)$ and in mixed swamp forest $\left(\sim 0.270 \mathrm{mg} \mathrm{N}_{2} \mathrm{O}-\mathrm{N} \mathrm{m}^{-2} \mathrm{~h}^{-1}\right)$ in Sarawak (Melling et al., 2008), and for secondary forest ( $\max .0 .584 \mathrm{mg} \mathrm{N}_{2} \mathrm{O}-$ $\mathrm{N} \mathrm{m}^{-2} \mathrm{~h}^{-1}$ ) in Amuntai, Indonesia (Hadi et al., 2005). In general, the DF site mean flux rate $\left(0.11 \mathrm{mg} \mathrm{N}_{2} \mathrm{O}\right.$ $\mathrm{N} \mathrm{m}^{-2} \mathrm{~h}^{-1}$ ) in this study is among the highest detected for tropical forest peat sites and compares with the reported mean flux of $0.157 \mathrm{mg} \mathrm{N}_{2} \mathrm{O}-\mathrm{N} \mathrm{m}^{-2} \mathrm{~h}^{-1}$ detected in secondary forest in Barabai in Indonesia (Hadi et al., 2000) and a mean flux of $0.086 \mathrm{mg} \mathrm{N}_{2} \mathrm{O}-\mathrm{N} \mathrm{m}^{-2} \mathrm{~h}^{-1}$ in regenerating forest in Central Kalimantan (Takakai et al., 2006).

Mean $\mathrm{N}_{2} \mathrm{O}$ fluxes measured at the UF $\left(0.003 \mathrm{mg} \mathrm{N}_{2} \mathrm{O}\right.$ $\left.\mathrm{N} \mathrm{m}^{-2} \mathrm{~h}^{-1}\right)$ and the DRF $\left(0.002 \mathrm{mg} \mathrm{N}_{2} \mathrm{O}-\mathrm{N} \mathrm{m}^{-2} \mathrm{~h}^{-1}\right)$ sites are small emissions, and within the mean flux range (from -0.020 to $0.1 \mathrm{mg} \mathrm{N}_{2} \mathrm{O}-\mathrm{N} \mathrm{m}^{-2} \mathrm{~h}^{-1}$ ) reported for pristine and secondary peat swamp forest sites in other studies 


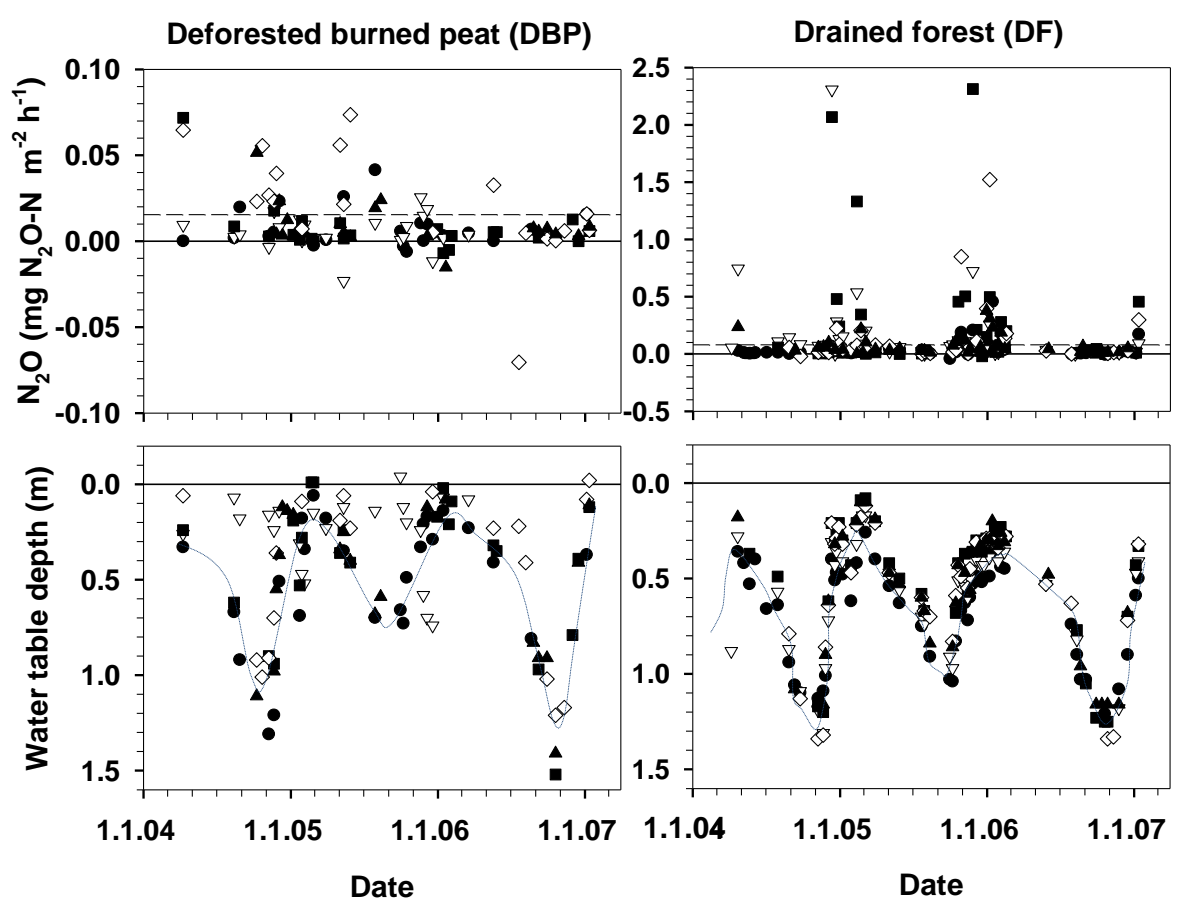

Fig. 4. $\mathrm{N}_{2} \mathrm{O}$ fluxes and the respective water table depth in the gas flux monitoring locations at the DF and DBP sites during the 2004-2007 period. Limits of the highly differing fluxes based on $75 \%$ quartiles (dash lines) are; $\geq 0.0806\left(\mathrm{mg} \mathrm{N}_{2} \mathrm{O}-\mathrm{N} \mathrm{m}^{-2} \mathrm{~h}^{-1}\right)$ at the DF site and $\geq 0.0155\left(\mathrm{mg} \mathrm{N}_{2} \mathrm{O}-\mathrm{N} \mathrm{m}^{-2} \mathrm{~h}^{-1}\right)$ at the DBP site. The different symbols denote specific five gas flux monitoring locations on the site.

(Inubushi et al., 2003; Furukawa et al., 2005; Takakai et al., 2006; Melling et al., 2007, 2008). Takakai et al. (2006) reported higher dry- and wet season mean $\mathrm{N}_{2} \mathrm{O}$ fluxes $\left(0.019\right.$ and $\left.0.055 \mathrm{mg} \mathrm{N}_{2} \mathrm{O}-\mathrm{N} \mathrm{m}^{-2} \mathrm{~h}^{-1}\right)$ for the same regenerating forest area as those measured at the DRF site in this present study. The $\mathrm{N}_{2} \mathrm{O}$ mean flux at the DBP site $\left(0.01 \mathrm{mg} \mathrm{N}_{2} \mathrm{O}-\mathrm{N} \mathrm{m}^{-2} \mathrm{~h}^{-1}\right)$ was within the reported range of flux means for abandoned lands (from -0.030 to $0.120 \mathrm{mg} \mathrm{N}_{2} \mathrm{O}-\mathrm{N} \mathrm{m}^{-2} \mathrm{~h}^{-1}$ ) in South- and Central Kalimantan (Hadi et al., 2000; Takakai et al., 2006). Furthermore, Takakai et al. (2006) reported a relatively similar mean $\mathrm{N}_{2} \mathrm{O}$ flux $\left(0.008 \mathrm{mg} \mathrm{N}_{2} \mathrm{O}-\mathrm{N} \mathrm{m}^{-2} \mathrm{~h}^{-1}\right)$ for an area with similar land use history close to the DBP site. The unfertilized agricultural site mean $\mathrm{N}_{2} \mathrm{O}$ flux rates $\left(0.012 \mathrm{mg} \mathrm{N}_{2} \mathrm{O}-\mathrm{N} \mathrm{m}^{-2} \mathrm{~h}^{-1}\right.$ for AP_Ka and $0.0072 \mathrm{mg}$ for AP_Ma, respectively) were much lower in comparison to the calculated mean of fertilized and unfertilized cultivated tropical peatlands, i.e. $0.442 \mathrm{mg} \mathrm{N}_{2} \mathrm{O}$ $\mathrm{N} \mathrm{m}^{-2} \mathrm{~h}^{-1}$ (Hadi et al., 2000, 2005; Furukawa et al., 2005; Takakai et al., 2006). However, Furukawa et al. (2005) reported similar and even lower mean fluxes for some agricultural lands.

Studies on boreal waterlogged peatlands have shown that denitrification, limited by the supply of mineral nitrogen, may be increased after drainage, as the diffusion of oxygen to the peat increases both mineralisation of organic matter and strictly aerobic nitrification processes. Enhanced nitrification further supplies nitrate for denitrification in the aero- bic/anaerobic interface, which can be seen as increased $\mathrm{N}_{2} \mathrm{O}$ emissions (Martikainen et al., 1993). Vegetation at the two selectively logged primary forests (UF and DF sites) was apparently similar and both forests could probably maintain comparably high rates of organic matter production, but the annual water table depth characteristics at these forests differed. The $\mathrm{N}_{2} \mathrm{O}$ fluxes were notably high within the 0.4$0.2 \mathrm{~m}$ water table depth range at the drained forest (DF) site, whose concurrent condition was close to that of the annual median water table depth $(0.35 \mathrm{~m}$ and $0.39 \mathrm{~m}$ for the years 2004/2005 and 2005/2006; Jauhiainen et al., 2008), or just slightly higher than mean water table depth during air sample collection (Table 2). The DF site forest floor was hardly ever covered by water (Fig. 4; Table 2). In addition to decomposition of peat substrate, continued supply of labile carbon and nitrogen compounds in recently deposited litter into the moderately moist and oxic conditions in the peat creates the potential for continued high aerobic decomposition at the drainage affected (DF site) forest (Jauhiainen et al., 2008), and thus a potential for high $\mathrm{N}_{2} \mathrm{O}$ emissions.

In the undrained UF forest both the mean water table depth of $0.1 \mathrm{~m}$ and also the water tables near the peat surface (both above and below the surface) resulted in high $\mathrm{N}_{2} \mathrm{O}$ flux rates (Fig. 2; Table 2). Flooding of the undrained forest may last up to six months annually (Takahashi et al., 2002; Jauhiainen et al., 2005), which limits the depth of the unsaturated peat profile and the duration of drained conditions. Water tables 

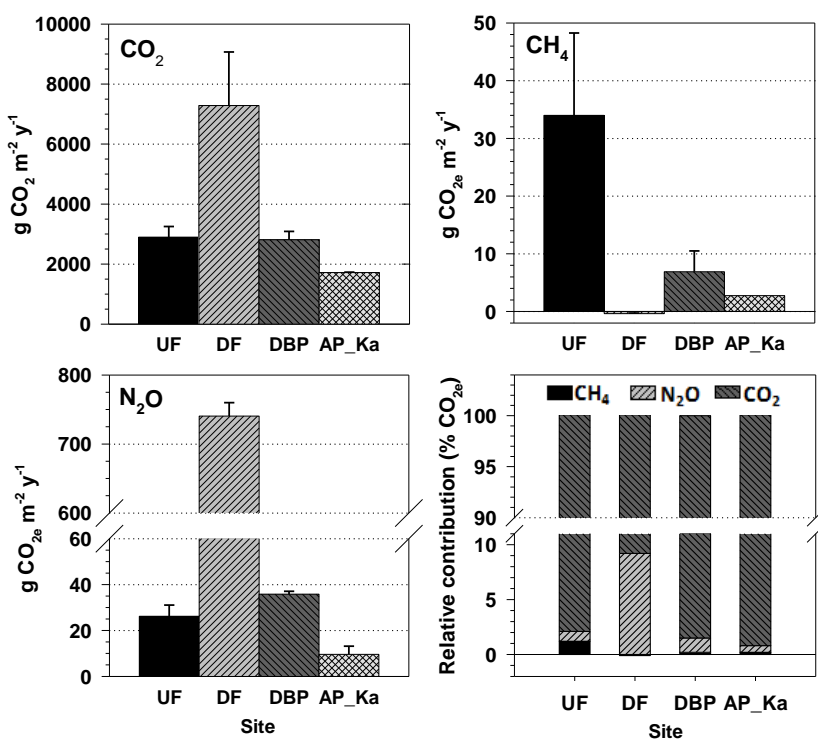

Fig. 5. Annual cumulative $\mathrm{CO}_{2}, \mathrm{CH}_{4}$ and $\mathrm{N}_{2} \mathrm{O}-\mathrm{N}$ fluxes (Mean \pm SD) expressed as $\mathrm{CO}_{2 \mathrm{e}}$ equivalents $\left(\mathrm{g} \mathrm{CO}_{2 \mathrm{e}} \mathrm{m}^{-2} \mathrm{yr}^{-1}\right)$ in peat based on 100 years perspective in radiative forcing, i.e. $\mathrm{CO}_{2}=$ $1, \mathrm{CH}_{4}=25, \mathrm{~N}_{2} \mathrm{O}=298$ (Solomon et al., 2007). Relative contribution of three gases to the total GWP $\left(\% \mathrm{CO}_{2 \mathrm{e}}\right)$ at sites is shown at lower right corner. Cumulative $\mathrm{CO}_{2}$ and $\mathrm{CH}_{4}$ flux rates and water table depth data; UF from Jauhiainen et al. (2005); DF and DBP from Jauhiainen et al. (2008), and AP_Ka from Hirano et al. (2009).

close to the peat surface (but below the surface) had a rather limited effect on the $\mathrm{N}_{2} \mathrm{O}$ fluxes at the UF site in this study. Nonetheless, it could be expected that general water level drawdown and increase in depth of moderately moist and aerobic peat would enhance fluxes in forest, as was indeed detected at the DF site. Flux data were collected at the UF site during the late phase of the dry season (August-September) and thus the possible flux peak during water level draw-down at the start of dry season or during rising water tables may have been missed at this site.

At the open DBP and agricultural sites, carbon and nitrogen inputs in litter were minimal due to the loss of tree cover and subsequent fires that had restricted vegetation regeneration. Fires consuming low biomass vegetation and peat may have temporarily enhanced nitrogen mineralization in the area (Takakai et al., 2006) but the impact on this study can be considered minimal because there was more than a two year period between the latest fire event and the start of flux monitoring. As a result of the preceding events, the peat $\mathrm{C}$ :N-ratio was relatively high at these sites (Table 2). Recalcitrant peat, containing relatively increasing amounts of complex polysaccharide substrates, found in this area (J. Jauhiainen, unpublished) is a poor resource for $\mathrm{N}$-mineralization. Thus low $\mathrm{N}$-mineralization did manifest as low/moderate $\mathrm{N}_{2} \mathrm{O}$ emissions at this site. Due to the long term shortage of notable litter inputs, oxidation $\mathrm{CO}_{2}$ emission rates were also relatively low at the DBP and AP_Ka sites (Jauhiainen et al., 2005, 2008; Hirano et al., 2009). The surface peat porosity in drained compacted peat was lower than that found in forest peat (Takakai et al., 2006). Takakai et al. (2006) suggests that this promotes the creation of anoxic conditions under increased peat moisture conditions which may lead to the potential predominance of $\mathrm{N}_{2}$ production in the denitrification process. Only modest background information is available for the AP_Ma site. However, low farming intensity, poor water management (drainage was limited by surrounding poorly drained areas), and a relatively short time period since the initial drainage are the suggested reasons for the higher $\mathrm{N}_{2} \mathrm{O}$ flux variation found at this site (Table 1, Fig. 2).

$\mathrm{N}_{2} \mathrm{O}$ influx was detected for all the sites, with the observed rates well within the GC detection limits. Most often these influxes were detected in wet, but not necessarily flooded, conditions. At sites where the original peat surface was lost by oxidation after drainage and fires (DBP and both AP sites), influxes were also recorded for deep water table depth conditions, which may have resulted in temporary anaerobic conditions created in the compacted peat. For example, anaerobic conditions may occur after a recent rain event as noted by Davidson et al. (2000). In general, detected $\mathrm{N}_{2} \mathrm{O}$ influx rates were fewer in number and smaller than the efflux rates at comparable water table depths (Figs. 2, 3, 4; Table 3). $\mathrm{N}_{2} \mathrm{O}$ influxes have also been reported in other studies on tropical peat for the following land-uses: abandoned arable field and secondary forest (Inubushi et al., 2003), deforested burned peat and regenerating forest (Takakai et al., 2006), oil palm and sago palm plantations and drainage-affected forest (Melling et al., 2007). Moreover, studies for other soil types under other climatic conditions have recorded influx events (Pihlatie et al., 2005; Hyvönen et al., 2009; Phillips and Podrebarack, 2009; Liu et al., 2010). Although the prerequisite of a potentially high labile carbon and nitrogen pool resulting from vegetation biomass dynamics was met at the DF and UF sites (Sulistiyanto, 2004), uncertainty remains about the actual mechanism involved in $\mathrm{N}_{2} \mathrm{O}$ influx, including the presence of bacterial strains capable of expressing the $\mathrm{N}_{2} \mathrm{O}$ reductase enzyme, or nitrate availability in the peat. In general, the mechanisms involved in soil $\mathrm{N}_{2} \mathrm{O}$ uptake are not very clear and need to be further studied.

\subsection{Spatial and temporal variation in $\mathrm{N}_{2} \mathrm{O}$ fluxes}

Spatial and temporal variations of fluxes were investigated in detail at the drained forest (DF) and open burned (DBP) sites. The main interest in the spatial and temporal variation was the high-level emissions in the $75 \%$ quartile, because most of the fluxes were small and evenly distributed over various water table conditions. The mean of high $\mathrm{N}_{2} \mathrm{O}$ efflux values at the DF site was about 10 times higher that of the DBP site. The high emission events at the DF site occurred when water tables were closer to the peat surface than those found at the DBP site, where these events were 
scattered over a wider range of water table depths. The monitoring locations at the DF site contributed relatively equally to this high emission group, i.e. about $20 \%$ contribution from three locations out of the five. Relative contributions to the high emission group varied more at the DBP site monitoring locations, and were between $8 \%$ and $44 \%$. Distance of monitoring locations from the drainage canal could not be causally connected to the number of high flux events because the order of these high flux events along with the monitoring transect locations was random. As noted earlier (Sect. 2.2.3), water table depths were comparable along both transects and therefore depth per se can not explain the differences.

Temporal factors also result in high $\mathrm{N}_{2} \mathrm{O}$ pulse events, and the evidence for this in the present study is mostly seen in the DF data where the highest effluxes tended to be associated with rising water table conditions during the early wet season. Thus the "temporal" effect could be also considered as "condition dependent". In the case of the DF site, the potential for emission peaks in these data appear to be created when the water table depth is close to the annual mode but above the annual mean depth (Table 2; Sect. 4.1). Reported fluxes from the same area as the DF and DRF sites, collected by Takakai et al. (2006), clearly show an increase in the $\mathrm{N}_{2} \mathrm{O}$ flux range after the onset of the wet season in November, whereas low soil moisture conditions resulted in low efflux. Increased frequency of water filtration through the peat and rising water tables after the onset of the wet season improve peat moisture conditions and, with sufficiently oxic conditions in the surface peat, will enhance decomposition of fine root and leaf litter deposited during drier conditions, resulting in the detected surge in $\mathrm{N}_{2} \mathrm{O}$ emissions at the DF site found in this study. How frequently such high $\mathrm{N}_{2} \mathrm{O}$ flux pulses occur, how long they last, and the spatial and temporal coverage of such flux hot spots remain to be studied in more detail.

\subsection{Cumulative $\mathrm{N}_{2} \mathrm{O}$ fluxes}

$\mathrm{N}_{2} \mathrm{O}$ emission at the DF site $\left(1581 \mathrm{mg} \mathrm{N}_{2} \mathrm{O}-\mathrm{N} \mathrm{m}^{-2} \mathrm{yr}^{-1}\right)$ was well above other reported mean cumulative emissions from forest growing on tropical peat (Inubushi et al., 2003; Takakai et al., 2006; Melling et al., 2007, 2008), except for reported emissions from a secondary forest site in Amuntai, Indonesia (1340 $\mathrm{mg} \mathrm{N}_{2} \mathrm{O}-\mathrm{N} \mathrm{m}^{-2} \mathrm{yr}^{-1}$; Hadi et al., 2005). The DF site annual $\mathrm{N}_{2} \mathrm{O}$ emission was at least 4-fold that of the next highest reported emissions $\left(60-400 \mathrm{mg} \mathrm{N}_{2} \mathrm{O}\right.$ $\mathrm{N} \mathrm{m}^{-2} \mathrm{yr}^{-1}$ ) in similar forest growing on peat in the study area (Takakai et al., 2006). One possible explanation for the large difference between cumulative emissions found at the DF site in this study and in the study by Takakai et al. (2006) might be that emissions in the latter were calculated by the direct multiplication of mean monthly fluxes (extrapolated from monitoring event readouts) with several days elapsing between the monitoring events. In contrast, the methodological approach used in this present study used daily peat water table depth values as a reference for flux extrapolation. Another explanation is that mean fluxes at the DF site have increased over a relatively short period of time after year 2002 (Figs. 2, 3; Tables 1, 3). The results presented by Takakai et al. (2006) also indicate an increasing trend in wet season mean $\mathrm{N}_{2} \mathrm{O}$ fluxes over time from 2002 to 2004 for this area.

The undrained forest (UF) annual $\mathrm{N}_{2} \mathrm{O}$ emission (55.9 $\mathrm{mg} \mathrm{N}_{2} \mathrm{O}-\mathrm{N} \mathrm{m}^{-2} \mathrm{yr}^{-1}$ ) was about $1 / 28$ th that of the DF site. It lies within the flux range reported for forests on tropical peat, i.e. from -50 to $1340 \mathrm{mg} \mathrm{N}_{2} \mathrm{O}-\mathrm{N} \mathrm{m}^{-2} \mathrm{yr}^{-1}$ (Inubushi et al., 2003; Takakai et al., 2006; Melling et al., 2007, 2008). The closest match among undrained forest emission rates is $120 \mathrm{mg} \mathrm{N}_{2} \mathrm{O}-\mathrm{N} \mathrm{m}^{-2} \mathrm{yr}^{-1}$ from Padang Alan forest in Sarawak (Melling et al., 2007). The drained, recovering DRF forest cumulative $\mathrm{N}_{2} \mathrm{O}$ emissions were not calculated in this study. However, Takakai et al. (2006) reported annual emissions of 40 and $400 \mathrm{mg} \mathrm{N}_{2} \mathrm{O}-\mathrm{N} \mathrm{m}^{-2} \mathrm{yr}^{-1}$ for similar forest types in the same area.

The deforested burned DBP site annual $\mathrm{N}_{2} \mathrm{O}$ emission of $76.4 \mathrm{mg} \mathrm{N}_{2} \mathrm{O}-\mathrm{N} \mathrm{m}^{-2} \mathrm{yr}^{-1}$ was close to the emissions reported for comparable land use types in the same area (97 and $150 \mathrm{mg} \mathrm{N}_{2} \mathrm{O}-\mathrm{N} \mathrm{m}^{-2} \mathrm{yr}^{-1}$; Takakai et al., 2006). In an earlier study, Inubushi et al. (2003) reported a notable annual $\mathrm{N}_{2} \mathrm{O}$ influx $\left(-37\right.$ and $-110 \mathrm{mg} \mathrm{N}_{2} \mathrm{O}-\mathrm{N} \mathrm{m}^{-2}$ ) for old abandoned croplands. The annual cumulative $\mathrm{N}_{2} \mathrm{O}$ emission $\left(20.6 \mathrm{mg} \mathrm{N}_{2} \mathrm{O}-\mathrm{N} \mathrm{m}^{-2}\right.$ ) for the agricultural AP_Ka site was the lowest in this study and is close to the lowest reported emission for peat used for agriculture in an earlier study (24.7 $\mathrm{mg} \mathrm{N}_{2} \mathrm{O}-\mathrm{N} \mathrm{m}^{-2} \mathrm{yr}^{-1}$; Hadi et al., 2005). Moreover, other studies reported calculated values of mean annual emission for agricultural peat $\left(7290 \mathrm{mg} \mathrm{N}_{2} \mathrm{O}-\mathrm{N} \mathrm{m}^{-2}\right)$, with the rates varying between 24.7 and $25900 \mathrm{mg} \mathrm{N}_{2} \mathrm{O}-$ $\mathrm{N} \mathrm{m}^{-2} \mathrm{yr}^{-1}$ (Hadi et al., 2000, 2005; Furukawa et al., 2005; Takakai et al., 2006). This wide emission range for agricultural peat is likely due to the greatly differing $\mathrm{N}$-fertilization practices between various sites.

Most of the published data on $\mathrm{N}_{2} \mathrm{O}$ fluxes are for boreal and temperate ecosystems (reviews by Kasimir-Klemedtsson et al., 1997; Maljanen et al., 2010). Cumulative $\mathrm{N}_{2} \mathrm{O}$ fluxes in peat swamp forest were much higher while peat fluxes for abandoned lands and for the AP_Ka and DBP sites in our study were much lower than those reported for undrained peat and drained fallow boreal peats. Maljanen et al. (2010) estimated the boreal undrained ombrotrophic peat annual $\mathrm{N}_{2} \mathrm{O}$ balance to be on average $<10 \mathrm{mg} \mathrm{N}_{2} \mathrm{O}-\mathrm{N} \mathrm{m}^{-2}$, while for drained fallow peat sites allocated to agricultural production the annual balance was $1360 \mathrm{mg} \mathrm{N}_{2} \mathrm{O}-\mathrm{N} \mathrm{m}^{-2}$ (range $800-2500 \mathrm{mg} \mathrm{m}^{-2} \mathrm{yr}^{-1}$ ). There was no heavily fertilized agricultural peat in our study. However, as discussed above, fertilized tropical peatlands generally have much higher $\mathrm{N}_{2} \mathrm{O}$ emissions in comparison to fertilized crop peatlands in boreal areas. 


\section{$4.4 \mathrm{~N}_{2} \mathrm{O}$ and $\mathrm{GWP}$}

Carbon dioxide was quantitatively the main emitted GHG from all sites in this study, and contributed $98 \%$ or more of the total GWP in the form of emissions of $\mathrm{CO}_{2}, \mathrm{CH}_{4}$ and $\mathrm{N}_{2} \mathrm{O}$. The highest cumulative $\mathrm{N}_{2} \mathrm{O}$ contribution to the total GWP (9.2\% of the total) occurred at the DF site (Fig. 5). It is worth noting that the DF site cumulative $\mathrm{CO}_{2}$ emission was the highest $\left(7283 \mathrm{~g} \mathrm{~m}^{-2} \mathrm{yr}^{-1}\right)$ in this study, which further adds absolute and relative significance to the $\mathrm{N}_{2} \mathrm{O}$ contribution. Cumulative $\mathrm{CH}_{4}$ losses only exceed those of $\mathrm{N}_{2} \mathrm{O}$ at the UF site (Fig. 5). In other studies, annual $\mathrm{N}_{2} \mathrm{O}$ fluxes have ranged from -0.5 to $5.1 \%$ of the total GWP of the three GHGs (based on Inubushi et al., 2003; Hadi et al., 2005; Melling et al., 2005a, 2005b, 2007, 2008). In comparison, Hadi et al. (2005) reported high annual $\mathrm{N}_{2} \mathrm{O}$ emission contributions of $4.7 \%\left(626.7 \mathrm{~g} \mathrm{CO}_{2 \mathrm{e}}\right)$ of the total GWP in secondary forest in Amuntai (Indonesia), where the $\mathrm{CO}_{2}$ emission was also very high $\left(12687 \mathrm{~g} \mathrm{~m}^{-2} \mathrm{yr}^{-1}\right)$, and $\mathrm{CH}_{4}$ emissions accounted for $1.1 \%$ of the total GWP.

In non-forest systems, $\mathrm{N}_{2} \mathrm{O}$ emissions have accounted for $3.7 \%$ of the total GWP in sago and $1.0 \%$ in oil palm plantation systems (Melling et al., 2005a, 2005b, 2007). In a study by Hadi et al. (2005), the relative contribution of $\mathrm{N}_{2} \mathrm{O}$ to total GWP was reported to be $1.3 \%$ in a rice-soybean rotation field, and $0.2 \%$ in a paddy field, whereas $\mathrm{CH}_{4}$ was the second most important GHG source (1.1-11.3\% of the total GWP) after $\mathrm{CO}_{2}$. It should be remembered that these reported $\mathrm{CO}_{2}$ emissions from tropical peat do not usually specifically separate the autotrophic emissions generated by live plants from the heterotrophic emissions that result from decomposition. As $\mathrm{N}_{2} \mathrm{O}$ and $\mathrm{CH}_{4}$ fluxes are from decomposition processes (only), the possible origin of $\mathrm{CO}_{2}$ emissions both from decomposition and also from root respiration processes complicates the accurate determination of total GWP flux balances for these three gases in soil. Therefore, $\mathrm{N}_{2} \mathrm{O}$ may make a much higher relative contribution to GWP from decomposition processes only. In addition, inclusion of highest peat $\mathrm{N}_{2} \mathrm{O}$ emissions (discussed in Sect.4.2) accurately in GHG emission budgets may require improvements in the monitoring techniques.

\subsection{Challenges and opportunities in $\mathrm{N}_{2} \mathrm{O}$ data collection and processing}

The undrained tropical peat swamp forest floor is a continuum of differing environmental conditions that are created by microtopography (hummock-hollow variation) and vegetation. It was noted earlier (Sect. 2.1), that gas flux monitoring devices used in this study were not set up on hummocks in order to avoid breaking the delicate root systems which largely form these structures. The base surface levels, i.e. hollows, were more uniform and naturally free of vegetation cover, which was partly due to high surface peat wetness during the wet season. This surface type selection probably accounts for the limited flux variation in the samples and also the increased comparability of fluxes between the forested sites. It is acknowledged, however, that much of the biomass turnover takes place in and on the hummocks, which form proportionally up to $50 \%$ of the peat surface of these sites (Jauhiainen et al., 2005). Open peatlands, i.e. open burned and agricultural land sites, had simpler structures than the forest peatland systems because there was either no vegetation or the herbaceous vegetation was sparsely scattered over the higher peat surfaces. The potential role of vegetation in determining $\mathrm{N} 2 \mathrm{O}$ flux remains to be studied. In this study, the limited capacity of the instrumentation enabled comparisons only of one typical peat surface type.

A major challenge in $\mathrm{N}_{2} \mathrm{O}$ emission monitoring is capturing the infrequent but very high fluxes that may occur on an irregular basis (Inubushi et al., 2003; Hadi et al., 2005; Takakai et al., 2006). Practically all $\mathrm{N}_{2} \mathrm{O}$ studies made on tropical peatlands are limited both by the low number of flux monitoring locations and the numbers of sampling events. There is a potential risk that the most important $\mathrm{N}_{2} \mathrm{O}$ flux observations may be excluded or undervalued. In this study, the data, especially those for the UF and RDF sites, suffer from temporal irregularity in air sampling during dry and wet seasons, therefore the possible peak emissions related to cyclic water table depth changes and simultaneous differences in litter decomposition activity may have been missed. Based on the magnitude and number of high $\mathrm{N}_{2} \mathrm{O}$ flux events detected, especially at the DF site, an even higher number of spatial and temporal replicates in flux monitoring are recommended. Air sampling with sufficient spatial replicates at each site should be made with an increased temporal intensity when the season is changing, in addition to monitoring during typical season conditions. Further investigations are required to determine whether such irregular high fluxes constitute an important component of the annual $\mathrm{N}_{2} \mathrm{O}$ flux. Such investigations might determine a better way for integration of these sporadic fluxes into the cumulative emission calculation. Comparable challenges apply to our understanding of the biological mechanisms facilitating negative $\mathrm{N}_{2} \mathrm{O}$ fluxes.

\section{Conclusions}

Drainage of tropical ombrotrophic forest systems increases organic matter mineralization rates in peat, although the litter deposition into peat may remain relatively unaffected. This results in enhanced GHG emissions, especially as $\mathrm{CO}_{2}$ and $\mathrm{N}_{2} \mathrm{O}$. The drained forest mean $\mathrm{N}_{2} \mathrm{O}$ flux was $>10$-fold in comparison to the fluxes for other sites, including mean flux in undrained peat swamp forest. For clear-felled sites (agricultural areas and deforested burned peat) emission rates were relatively modest, and this is associated with low $\mathrm{N}$ availability in the peat substrate. Therefore, enhanced $\mathrm{N}_{2} \mathrm{O}$ emission rates from drained peat after land use change can be a transient phenomenon when the nitrogen availability is 
not maintained at a high level from biological or artificial sources. The $\mathrm{N}_{2} \mathrm{O}$ flux rates show some degree of spatial and temporal variation in drained forest and deforested drained peatland. More intensive flux monitoring investigations on tropical peat soils are required in order to be confident that the impacts of very high, but potentially short-lived, fluxes are properly determined. It is possible that in annual $\mathrm{N}_{2} \mathrm{O}$ flux budgets the peak fluxes are still underestimated due to insufficient replicates from collection or poor data modeling of stochastic peak mission events. Carbon dioxide has an outstanding GWP impact ( $>90 \%)$ in tropical peat when concurrent $\mathrm{CO}_{2}, \mathrm{CH}_{4}$ and $\mathrm{N}_{2} \mathrm{O}$ fluxes are compared across various land use types.

Acknowledgements. This work is the result of nearly 10-years of data collection supported by the EU INCO DC programmes; EUTROP, STRAPEAT, RESTORPEAT, and the Academy of Finland funded projects (KEYTROP and TROPEASS). Our special thanks are also due to colleagues who contributed a lot of their time to the gas sampling, especially Yarden Tundan and Nyahu Rumbang from CIMTROP. AusAid (Australian Government Overseas Development Program). KFCP program is thanked for financial support. Four referees are thanked for their constructive input.

Edited by: D. Zona

\section{References}

Davidson, E. A., Swank, W. T., and Perry, T. O.: Distinguishing be- tween nitrification and denitrification as sources of gaseous nitrogen production in soil, Appl. Environ. Microbiol., 52, 12801286, 1986.

Davidson, E. A., Keller, M., Erikson, H. E., Verchot, L. V., and Veldkamp, E.: Testing a conceptual model of soil emissions of nitrous and nitric oxide, Bioscience, 50, 667-680, 2000.

Ehhalt, D., Prather, M., Dentener, F., Derwent, R., Dlugokencky, E., Holland, E., Isaksen, I., Katima, J., Kirchhoff, V., Matson, P., Midgley, P., and Wang, M.: Atmospheric chemistry and greenhouse gases, in: Climate Change: The Scientific Basis, edited by: Houghton, J. T. and Ding, Y., Cambridge University Press, Cambridge, 239-288, 2001.

Furukawa, Y., Inubushi, K., Ali, M., Itang, A. M., and Tsuruta, H.: Effect of changing groundwater levels caused by land-use changes on greenhouse gas emissions from tropical peatlands, Nutr. Cycl. Agroecosys., 71, 81-91, 2005.

Germer, J. and Sauerborn, J.: Estimation of the impact of oil palm plantation establishment on greenhouse gas balance, Environ. Dev. Sustain., 10, 697-716, 2008.

Hadi, A., Inubushi, K., Purnomo, E., Razie, F., Yamakawa, K., and Tsuruta, H.: Effect of land-use change on nitrous oxide $\left(\mathrm{N}_{2} \mathrm{O}\right)$ emission from tropical peatlands, Chemosphere, 2, 347-358, 2000.

Hadi, A., Inubushi, K., Furukawa, Y., Purnomo, E., Rasmadi, M., and Tsuruta, H.: Greenhouse gas emissions from tropical peatlands of Kalimantan, Indonesia, Nutr. Cycl. Agroecosys., 71, 73$80,2005$.
Hashidoko, Y., Takakai, F., Toma, Y., Darung, U., Melling, L., Tahara, S., and Hatano, R.: Emergence and behaviors of acidtolerant Janthinobacterium sp. that evolves $\mathrm{N}_{2} \mathrm{O}$ from deforested tropical peatland, Soil Biol. Biochem., 40, 116-125, 2008.

Hirano, T., Jauhiainen, J., Inoue, T., and Takahashi, H.: Controls on the carbon balance of tropical peatlands, Ecosystems, 12, 873887, 2009.

Hooijer, A., van der Vat, M., Prinsen, G., Vernimmen, R., Brinkman, J., and Zijl, F.: Hydrology of the EMRP Area: Water Management Implications for Peatlands. Technical Report Number 2. Euroconsult Mott MacDonald and Deltares | Delft Hydraulics in association with DHV, Wageningen UR, Witteveen+Bos, PT MLD and PT INDEC, 131 pp., 2008.

Hoscilo, A., Page, S. E., Tansey, K. J., and Rieley, J. O.: Effect of repeated fires on land-cover change on peatland in southern Central Kalimantan, Indonesia, from 1973 to 2005, Int. J. Wildland Fire, 20, 578-588, 2011.

Hyvönen, N. P., Huttunen, J. T., Shurpali, N. J., Tavi, N. M., Repo, M. E., and Martikainen, P. J.: Fluxes of nitrous oxide and methane on an abandoned peat extraction site: Effect of reed canary grass cultivation, Bioresource Technol., 100, 4723-4730, 2009.

Inubushi, K., Furukawa, Y., Hadi, A., Purnomo, E., and Tsuruta, $\mathrm{H}$.: Seasonal changes of $\mathrm{CO}_{2}, \mathrm{CH}_{4}$ and $\mathrm{N}_{2} \mathrm{O}$ fluxes in relation to land-use change in tropical peatlands located in coastal area of South Kalimantan, Chemosphere, 52, 603-608, 2003.

Jauhiainen, J., Takahashi, H., Heikkinen, J. E. P., Martikainen, P. J., and Vasander, H.: Carbon fluxes from a tropical peat swamp forest floor, Global Change Biol., 11, 1788-1797, 2005.

Jauhiainen, J., Limin, S., Silvennoinen, H., and Vasander, H.: Carbon dioxide and methane fluxes in drainage affected tropical peat before and after hydrological restoration, Ecology, 89, 35033514, 2008.

Jauhiainen, J., Hooijer, A., and Page, S. E.: Carbon dioxide emissions from an Acacia plantation on peatland in Sumatra, Indonesia, Biogeosciences, 9, 617-630, doi:10.5194/bg-9-617-2012, 2012.

Kasimir-Klemedtsson, Å., Klemedtsson, L., Berglund, K., Martikainen, P., Silvola, J., and Oenema, O.: Greenhouse gas emissions from farmed organic soils: a review, Soil Use Manage., 13, 245-250, 1997.

Kiese, R., Hewett, B., Graham, A., and Butterbach-Bahl, K.: Seasonal variability of $\mathrm{N}_{2} \mathrm{O}$ emissions and $\mathrm{CH}_{4}$ uptake by tropical rainforest soils of Queensland, Australia, Global Biogeochem. Cy., 17, 1043-1054, 2003.

Laiho, R., Vasander, H., Penttilä, T., and Laine, J.: Dynamics of plant-mediated organic matter and nutrient cycling following water-level drawdown in boreal peatlands, Global Biogeochem. Cy., 17, 1053, doi:10.1029/2002GB002015, 2003.

Liu, X.-R., Dong, Y.-S., Qi, Y.-C., and Li, S. G.: $\mathrm{N}_{2} \mathrm{O}$ fluxes from the native and grazed semi-arid steppes and their driving factors in Inner Mongolia, China, Nutr. Cycl. Agroecosyst., 86, 231240, 2010.

Maljanen, M., Martikkala, M., Koponen, H. T., Virkajärvi, P., and Martikainen, P. J.: Fluxes of nitrous oxide and nitric oxide from experimental excreta patches in boreal agricultural soil, Soil Biol. Biochem., 39, 914-920, 2007.

Maljanen, M., Sigurdsson, B. D., Gudmundsson, J., Óskarsson, H., Huttunen, J. T., and Martikainen, P. J.: Greenhouse gas balances 
of managed peatlands in the Nordic countries present knowledge and gaps, Biogeosciences, 7, 2711-2738, doi:10.5194/bg7-2711-2010, 2010.

Martikainen, P. J., Nykänen, H., Crill, P., and Silvola, J.: Effect of a lowered water table on nitrous oxide from northern peatland, Nature, 366, 51-53, 1993.

Melling, L., Hatano, R., and Goh, K. J.: Soil $\mathrm{CO}_{2}$ flux from three ecosystems in tropical peatland of Sarawak, Malaysia, Tellus, 57, 1-11, 2005a.

Melling, L., Hatano, R., and Goh, K. J.: Methane fluxes from three ecosystems in tropical peatland of Sarawak, Malaysia, Soil Biol. Biochem., 37, 1445-1453, 2005 b.

Melling, L., Hatano, R., and Goh, K. J.: Nitrous oxide emissions from three ecosystems in tropical peatland of Sarawak, Malaysia, Soil Sci. Plant Nutr., 53, 792-805, 2007.

Melling, L., Uyo, L. J., Goh, G. J., Ryusuke, H., and Osaki, M.: Greenhouse gas fluxes of Loagan Bunut national park, Sarawak, Malaysia, Final report of Peat Swamp Forests Project UNDP/GEF, 73 pp., 2008.

Miettinen, J. and Liew, S. C.: Degradation and development of peatlands in peninsular Malaysia and in the islands of Sumatra and Borneo, Land Degrad. Dev., 21, 285-296, 2010.

Moore, T. R. and Knowles, R.: The influence of water table levels on methane and carbon dioxide emissions from peatland soils, Can. J. Soil Sci., 69, 33-38, 1989.

Murdiyarso, D., Hergoualc'h, K., and Verchot, L. V.: Opportunities for reducing greenhouse gas emissions in tropical peatlands, $\mathrm{P}$. Natl. Acad. Sci., 107, 19655-19660, 2010.

Mäkiranta, P., Hytönen, J., Aro, L., Maljanen, M., Pihlatie, M., Potila, H., Shurpali, N., Laine, J., Lohila, A., Martikainen, P.J., and Minkkinen, K.: Soil greenhouse gas emissions from afforested organic soil croplands and cutaway peatlands, Boreal Environ. Res., 12, 159-175, 2007.

Nykänen, H., Alm, J., Lång, K., Silvola, J., and Martikainen, P. J.: Emissions of $\mathrm{CH}_{4}, \mathrm{~N}_{2} \mathrm{O}$ and $\mathrm{CO}_{2}$ from a virgin fen and a fen drained for grassland in Finland, J. Biogeogr., 22, 351-357, 1995.

Page, S. E., Siegert, F., Rieley, J. O., Böhm, H.-D. V., Jaya, A., and Limin, S.: The amount of carbon released from peat and forest fires in Indonesia during 1997, Nature, 420, 61-65, 2002.

Page, S. E., Rieley, J. O., and Banks, C. J.: Global and regional importance of the tropical peatland carbon pool, Global Change Biol., 17, 798-818, 2011.
Phillips, R. L. and Podrebarac, F.: Net fluxes of $\mathrm{CO}_{2}$, but not $\mathrm{N}_{2} \mathrm{O}$ or $\mathrm{CH}_{4}$, are affected following agronomic-scale additions of urea to prairie and arable soils, Soil Biol. Biochem., 41, 2011-2013, 2009.

Pihlatie, M., Rinne, J., Ambus, P., Pilegaard, K., Dorsey, J. R., Rannik, Ü., Markkanen, T., Launiainen, S., and Vesala, T.: Nitrous oxide emissions from a beech forest floor measured by eddy covariance and soil enclosure techniques, Biogeosciences, 2, 377387, doi:10.5194/bg-2-377-2005, 2005.

Solomon, S., Quin, D., Manning, M., Marquis, M., Averyt, K., Tignor, M. M. B., Miller, H. L.-R., and Chen, Z.: Climate Change 2007: The Physical Science Basis - Summary for Policymakers, Contribution of working group I to the fourth assessment report of the IPCC Cambridge University Press, Cambridge, 18 pp., 2007.

Sulistiyanto, Y.: Nutrient dynamics in different sub-types of peat swamp forest in Central Kalimantan, Indonesia. Ph.D. thesis, University of Nottingham, UK, 351 pp., 2004.

Takahashi, H., Shimada, S., Ibie, B. I., Usup, A., Yudha, and Limin, S. H.: Annual changes of water balance and a drought index in a tropical peat swamp forest of Central Kalimantan, Indonesia, in: Peatlands for People: Natural Resource Functions and Sustainable Management, Proceedings of the International Symposium on Tropical Peatland, 22-23 August 2001, Jakarta, Indonesia, edited by: Rieley, J. O., Page, S., with Setiadi, B., BPPT and Indonesian Peat Association, 63-67, 2002.

Takakai, F., Morishita, T., Hashidoko, Y., Darung, U., Kuramochi, K., Dohong, S., Limin, S. H., and Hatano, R.: Effects of agricultural land-use change and forest fire on $\mathrm{N}_{2} \mathrm{O}$ emission from tropical peatlands, Central Kalimantan, Indonesia, Soil Sci. Plant Nutr., 52, 662-674, 2006.

Yanai, Y., Toyota, K., Morishita, T., Takakai, F., Hatano, R., Limin, S. H., Darung, U., and Dohong, S.: Fungal $\mathrm{N}_{2} \mathrm{O}$ production in an arable peat soil in Central Kalimantan, Indonesia, Soil Sci. Plant Nutr., 53, 806-811, 2007. 